\title{
ЭКСПОРТ РОССИЙСКОГО ВЫСШЕГО ОБРАЗОВАНИЯ ЗА РУБЕЖ: НОРМАТИВНО-ПРАВОВОЕ РЕГУЛИРОВАНИЕ И СТРАТЕГИЧЕСКИЕ ЦЕЛИ РАЗВИТИЯ "
}

\author{
(c) 2019 Щукина Татьяна Владимировна \\ доктор юридических наук, доцент, заведующая кафедрой прикладного права \\ Российский Технологический Университет - МИРЭА, Россия, Москва \\ профессор кафедры административного и финансового права \\ Липецкий филиал РАНХиГС, Россия, Липецк \\ E-mail: shukina-tv@mail.ru
}

Предметом настоящей статьи выступает исследование теоретических и практических представлений о правовом регулировании экспорта российского высшего образования за рубеж; рассмотрение стратегических целей и направлений развития экспорта высшего образования. Тема статьи отражает вопросы трансформации современной системы высшего образования с точки зрения интернационализации и международной интеграции образовательных программ; новых особенностей правового регулирования «прорыва» в системе высшего образования. Целью настоящей статьи являются выявление на современном этапе международных и национальных условий преобразования системы высшего образования, места и роли государства и университетов в этом процессе. Методологию данной работы составили сравнительный, формально-юридический, аналитический методы. Результаты работы - это формулирование особенностей экспорта российского высшего образования. Область применения результатов работы включает в себя систему управления высшим образованием. Выводы исследования могут быть использованы для дальнейшего совершенствования правовой регламентации и практики организации высшего образования в России.

Ключевые слова: новое нормативное правовое регулирование международной интеграции высшего образования, международные и национальные стратегии преобразования системы высшего образования.

Вопросы экспорта высшего образования за рубеж являются актуальными и востребованными не только в Российской Федерации, но и во всех зарубежных странах. Интеграция образования и гармоничное встраивание его отдельных элементов в образовательном процессе иностранных образовательных организаций на основе партнерства с другими университетами позволяет формировать мобильную, интересную и инновационную образовательную среду. Экспорт образования дает множество импульсов к развитию не только собственного образовательного процесса и его экосреды, но и к распространению российской культуры, языка и традиций в других странах; к созданию новых идей, их реализации и продвижению новых коммуникаций и университетского сотрудничества.

Важность экспорта образования в Российской Федерации признана на государственном уровне и закреплена в национальных задачах стратегического развития государства [1]. В соответствии с национальными целями были утверждены на заседании Совета при Президенте Российской Федерации по стратегическому развитию и национальным проектам паспорта национальных проектов «Образование» [2] и «Наука» [3]. Действующая система национальных проектов направлена на получение конкретных результатов социального и экономического благополучия страны.

Относительно процесса модернизации образования в настоящее время действуют несколько основных федеральных нормативных правовых актов, включая государственную программу Российской Федерации «Развитие образования» и паспорт национального проекта «Образование». Государственная пилотная программа «Развитие образования» поглощает этот национальный

\footnotetext{
" Статья подготовлена в рамках гранта РФФИ 19-011-00959 «Моделирование экспорта высшего образования в рамках новых стратегий публичного управления в Российской Федерации» 2019-2021 г.г.
} 
проект и предусматривает такие направления, как: 1) «Развитие среднего профессионального и дополнительного профессионального образования», 2) «Развитие дошкольного и общего образования», 3) «Развитие дополнительного образования детей и реализация мероприятий молодежной политики», 4) «Совершенствование управления системой образования». Собственно национальный проект в большей степени конкретизирует реализацию государственной пилотной программы. Проект направлен на выполнение десяти федеральных проектов. К ним относятся: 1) «Современная школа», 2) «Успех каждого ребенка», 3) «Поддержка семей, имеющих детей», 4) «Цифровая образовательная среда», 5) «Учитель будущего», 6) «Молодые профессионалы», 7) «Новые возможности для каждого», 8) «Социальная активность», 9) «Экспорт образования», 10) «Социальные лифты для каждого».

Согласно паспорту национального проекта «Образование» - это две глобальных цели: 1) обеспечение глобальной конкурентоспособности российского образования, вхождение Российской Федерации в число 10 ведущих стран мира по качеству общего образования; 2) воспитание гармонично развитой и социально ответственной личности на основе духовно-нравственных ценностей народов Российской Федерации, исторических и национально-культурных традиций.

В настоящее время в Рейтинге стран мира по уровню образования, проводимому ООН в 2018 году, Российская Федерация заняла 32 место из 189 стран. В десятку входят Германия, Дания, Великобритания, Финляндия, Нидерланды и другие. США в списке двенадцатые. По рейтингам качества образования в университетах мира Российская Федерация занимает определенное место, зависящее от рейтинга соответствующего университета. Так, по общеизвестному рейтингу QS (World University Ranking) наши известные университеты располагаются в списке, начиная с 95 места: МГУ - 95 место, СпбГУ - 240 место и завершает ВГУ, занимающий 801-100 место. В рейтинге лучших юридических школ МгУ занимает 51 место, а ВШЭ, СПбГУ лишь 151-200 места (на уровне Египта) [4]. Это достаточно слабые позиции в мире, лидерами рейтинга QS в течение многих лет стабильно являются вузы США и Великобритании. Конечно, рейтинги очень субъективная вещь и формируются они, как правило, агентствами Великобритании и США, но поводом к размышлению и серьезным действиям рейтинговые оценки являются. По рейтингам, формируемым российскими агентствами, университеты Российской Федерации занимают очень достойное положение и входят в десятку лучших вузов.

Результатами национального проекта «Образование» к 2024 году должны стать: 1) 10 место РФ в мире по присутствию университетов в ТОП-500 глобальных рейтингов университетов, начиная от 17 места, 2) 80 процентов - доля детей в возрасте от 5 до 18 лет, охваченных дополнительным образованием; 3) 8,8 млн. человек - численность обучающихся, вовлеченных в деятельность общественных объединений на базе образовательных организаций общего образования, среднего и высшего профессионального образования. Конечно же, достижение конкретных целевых показателей каждого из федеральных проектов этого нацпроекта. А в целом - сделать образование современным, доступным, интересным и качественным для всех групп населения, включая людей серебряного возраста.

Замысел федерального проекта «Экспорт образования» нацелен на увеличение не менее, чем в два раза количества иностранных граждан, обучающихся в образовательных организациях высшего образования и научных организациях, а также реализацию комплекса мер по трудоустройству лучших из них в РФ. Для этого к 2024 году должны быть достигнуты следующие целевые показатели:

1) сформирована система летних и зимних школ, филиалов и представительств российских организаций, находящихся за рубежом, для привлечения иностранных граждан с целью последующего приема на обучение по программам высшего образования: не менее 15 тысяч иностранных граждан ежегодно;

2) созданы современные многофункциональных студенческих городков, обеспечивающих комфортные условия проживания, возможность проведения учебных занятий обучающихся мощностью: не менее 66 тысяч мест;

3) спроектированы обновляемые версии официальных сайтов в сети «Интернет» на иностранных языках, ориентированных на запросы иностранных абитуриентов и студентов: не менее 10 сайтов;

4) сформирована сеть ресурсных центров для детей и педагогов, обеспечивающих популя- 
ризацию изучения общеобразовательных предметов (математика, биология, химия, физика, астрономия и другие) на углубленном уровне (на русском языке) в странах-партнерах, в том числе с использованием сети Россотрудничества: не менее 50 ресурсных центров;

5) привлечены иностранные граждане для обучения в России по программам высшего образования с целью их последующего трудоустройства в российских и транснациональных компаниях за рубежом: в 2019 г.- 241 тыс. человек, в 2020 г.- 268 тыс. человек, в 2021 г.302 тыс. человек, в 2022 г.- 341 тыс. человек, в 2023 г. - 382 тыс. человек, в 2024 г. - 425 тыс. человек. Планируется трудоустроить не менее 5\% лиц из числа иностранных студентов, завершивших обучение в области востребованных направлений подготовки, в российских компаниях. По итогам международных и российских олимпиад и конкурсов будет отобрано не менее 20\% иностранных граждан от общего числа иностранных граждан, принятых на первый курс, для обучения в российских организациях, осуществляющих образовательную деятельность по образовательным программам высшего образования, по востребованным (дефицитным) направлениям подготовки, специальностям;

6) не менее $5 \%$ преподавателей организаций, осуществляющих образовательную деятельность по образовательным программам высшего образования и дополнительным профессиональным программам, реализуют учебные дисциплины, курсы (модули) на иностранном языке. К 2024 году не менее 60 университетов реализуют не менее чем по 5 образовательных программ, прошедших международную аккредитацию.

В 2019 году на федеральном уровне должна быть подготовлена вся нормативная документация по внедрению экспорта образования. И пилотные вузы России, а их более 34 университетов, будут реализовывать мероприятия по экспорту образования: международные летние школы, строительство международных кампусов, привлечение на обучение иностранных студентов, подготовка по международным англоязычным образовательным программам магистратуры и бакалавриата, обмен студентами и преподавателями. Уже сейчас университеты, входящие в ТОП-50 разрабатывают и реализуют образовательные программы магистратуры, совмещенные с получением степени Ph D.
Все федеральные проекты успешно реализуются, и каждый субъект Российской Федерации включен в их исполнение. В большей степени, нацпроект «Образование» направлен на дошкольное, школьное и среднее профессиональное образование, поэтому руководит им министерство Просвещения Российской Федерации. Высшие учебные заведения имеют право точечно принять участие в мероприятиях федеральных проектов в рамках национального проекта «Образование». Это четыре федеральных проекта - «Экспорт образования», «Молодые профессионалы», «Новые возможности для каждого»и «Социальная активность». Часть федеральных проектов, в которых принимают участие организации высшего образования, относятся к национальному проекту «Наука».

Национальные проекты «Наука» и «Образование», несмотря на разных руководителей и исполнение со стороны двух федеральных министерств, взаимно связаны и обладают точками соприкосновения по некоторым целям, целевым показателям и результатам проектов. Главная стратегическая цель, которая их объединяет, это - обеспечение глобальной конкурентоспособности российского образования и науки. Это: а) вхождение Российской Федерации в число 10 ведущих стран мира по качеству общего образования; б) присутствие российских университетов ТОП-500 глобальных рейтингов [5] университетов, в) присутствие Российской Федерации в числе пяти ведущих стран мира, осуществляющих научные исследования и разработки в областях [5] научно-технологического развития. Подобная глобальная цель требует реализации таких целей, как достижение численности исследователей в эквиваленте полной занятости среди ведущих стран мира; по удельному весу в общем числе статей в областях, определяемых приоритетами научно-технологического развития, в изданиях, индексируемых в международных базах данных и других [5].

Следует отметить, те цели и целевые показатели национального проекта «Наука», достижение которых обязательно обеспечит экспорт высшего российского образования за рубеж. Указ Президента РФ от 7 мая 2018 г. № 204 «О национальных целях и стратегических задачах развития Российской Федерации на период до 2024 года» предусматривает в сфере науки обеспечение следующих целей и целевых показателей, как: 1) обеспечение привлекательности работы 
в РФ для российских и зарубежных ведущих ученых, молодых перспективных исследователей; 2) опережающее увеличение внутренних затрат на научные исследования и разработки за счет всех источников (по сравнению с ростом валового внутреннего продукта [5] страны).

А одной из стратегических задач в области науки выступает формирование целостной системы подготовки и профессионального роста научных и научно-педагогических кадров, обеспечивающей условия для осуществления молодыми учеными научных исследований и разработок, создания научных лабораторий и конкурентоспособных [5] коллективов. Остальные задачи, касающиеся обновления научной сферы и способствующие экспорту высшего российского образования за рубеж, сформулируем так: 1) создание и развитие сети уникальных научных установок класса MegaScience; 2) обновление $50 \%$ и более процентов приборной базы ведущих научно-исследовательских организаций, 3) создание 15 научно-образовательных центров мирового уровня на основе интеграции университетов и научных организаций, 4) создание научных центров мирового уровня, включая центры по математике и геномным исследованиям.

В итоге отметим, что университеты путем коллаборации между собой, а также школами, средними профессиональными учебными заведениями, СО НКО могут помочь органам государственной власти в реализации не только нацпроектов «Образование» и «Наука», но и других проектов. Например, нацпроекта, касающегося повышения производительности труда, мероприятий Национальной технологической инициативы. По-сути, необходимо создание цифровой или научно-исследовательской платформы, на которой объединятся все образовательные организации и социально-ориентированные некоммерческие организации, благотворительные фонды, а лучше еще и предприниматели. И она станет мощной основой для эффективного выполнения целевых показателей всех нацпроектов в целом. С инициативой создания региональных центров компетенций как научноисследовательской платформы автор данного грантового проекта обратилась в комитет Совета Федерации Федерального Собрания РФ по науке, образованию и культуре.

\section{Библиографический список}

1. О национальных целях и стратегических задачах развития Российской Федерации на период до 2024 года: указ Президента РФ от 7 мая 2018 г. N204 // Собр. законодательства Рос. Федерации. 2018. N20. Ст. 2817.

2. Паспорт национального проекта «Образование», утв. президиумом Совета при Президенте Российской Федерации по стратегическому развитию и национальным проектам (протокол от 24 декабря 2018 г. N16)

3. Паспорт национального проекта «Наука», утв. президиумом Совета при Президенте Российской Федерации по стратегическому развитию и национальным проектам (протокол от 24 декабря 2018 г. N16)

4. Times Higher Education World University Rankings 2019. URL: https:// www.timeshighereducation. com/worlduniversity-rankings/2019/world-ranking\#! /page/0/ length/25/sort_by/rank/sort_order/ asc/ cols/ stats

5. Паспорт национального проекта «Образование», утв. президиумом Совета при Президенте Российской Федерации по стратегическому развитию и национальным проектам (протокол от 24 декабря 2018 г. N16) 